\title{
A palace for the king of Eres? Evidence from the Early Dynastic City of Abu Salabikh, south Iraq
}

Book or Report Section

Published Version

Matthews, R. and Matthews, W. (2017) A palace for the king of Eres? Evidence from the Early Dynastic City of Abu Salabikh, south Iraq. In: Heffron, Y., Stone, A. and Worthington, M. (eds.) At the dawn of history. Ancient Near Eastern studies in honour of J. N. Postgate. Eisenbrauns, Winona Lake, pp. 359367. ISBN 9781575064710 Available at http://centaur.reading.ac.uk/68878/

It is advisable to refer to the publisher's version if you intend to cite from the work. See Guidance on citing.

Publisher: Eisenbrauns

All outputs in CentAUR are protected by Intellectual Property Rights law, including copyright law. Copyright and IPR is retained by the creators or other 
copyright holders. Terms and conditions for use of this material are defined in the End User Agreement.

\section{www.reading.ac.uk/centaur}

\section{CentAUR}

Central Archive at the University of Reading

Reading's research outputs online 


\title{
A Palace for the King of Ereš? Evidence from the Early Dynastic City of Abu Salabikh, South Iraq
}

\author{
Roger Matthews and Wendy Matthews
}

For Nicholas, in memory of happy days at Abu Salabikh

\section{Political Authority in Early Sumer: The Nature of the Problem and of the Evidence}

The nature of political authority in Sumer (south Mesopotamia/south Iraq) during the early development of urban societies in the period $c a .3200-2350 \mathrm{BC}$ has been a much debated topic since the first recovery of relevant evidence from excavations in Iraq during the early decades of Mesopotamian archaeology (Matthews 2003, 8-12). Initial proposals of the Sumerian city-state as dominated by religious authority, the so-called Sumerian Temple State theory proposed by Deimel (1920; 1931), Schneider (1920) and Falkenstein (1954; 1974; reviewed in Gibson 2010), have been succeeded by more subtle formulations of "constellations of authority in early complex polities" (Smith 2003). These interpretations articulate conceptions of a role for kings and kingship not solely in times of crisis or warfare (Jacobsen 1957) but also as delegates of the gods with responsibilities transcending secular and divine fields of authority (Liverani 2014, 107-109), and combining public and private components (Gelb 1969; Diakonoff 1974; Foster 1981; Suter 2013). Also of significance in understanding early political authority in Sumer has been the evidence from texts and clay sealings in what appear to be large private houses, which suggest the participation of individual householders within large-scale, city-level administrative activities (Martin 1988; Matthews 1991; Starzmann 2007).

Evidence adduced in discussion of early Sumerian political authority has been drawn from two sources: excavated information from relevant archaeological sites in south Iraq and beyond, and cuneiform texts from the periods in question. There are severe problems as regards both fields of evidence. For the archaeology, very few excavations at appropriate sites in south Iraq have taken place for a quarter of a century, and many of those that did take place prior to 1990 did not recover or publish evidence relevant to this topic. For the cuneiform texts, the main problem remains the fact that the vast majority were recovered from late nineteenth century and early twentieth century excavations in Iraq that failed to articulate secure archaeological contexts for the texts in question. Even where architectural and stratigraphic contexts were definable, as in the late fourth millennium texts from Uruk (Englund 1998) or the mid-third millennium texts from Fara and Abu Salabikh (Krebernik 1998; Krebernik and Postgate 2009), it is clear that these contexts are more often secondary or even tertiary to the texts' original places of inscription and use. 
Critical to the rise and sustainability of politically powerful groups within early Sumerian societies was access to and control over the differential distribution of natural resources across the regions of the ancient Middle East. The lowland zones of Sumer were rich in a wide range of useful resources, including water, clay, reeds, date-palms, bitumen and limestone (summarised in Algaze 1993, 2-5; Potts 1997, 91-121; Van De Mieroop 2002, 126-128). The adjacent highland zones, by contrast, contained ample deposits of commodities such as metals (copper, tin, silver, gold), semi-precious and other stones (lapis lazuli, carnelian, turquoise, chlorite), and building timber (Moorey 1999). Fluctuations through time in the scope and intensity of imported materials into Sumer can be seen as diagnostic of the ebb and flow of political power in the cities and city-states of the Sumerian heartland.

Van De Mieroop (2002) has argued that from about $2600 \mathrm{BC}$ there was a step-change in the engagement of Sumerian polities with the wider world, comprising a major increase in the import of cherished commodities such as gold, silver, lapis lazuli, carnelian and chlorite, most richly attested in the Royal Cemetery of Ur (Zettler and Horne 1998), accompanied by historical evidence for external engagement of Sumerian leaders in military encounters with regions to the north, east and west. Van De Mieroop intertwines the three threads of luxury consumption, external contacts and the presence of a social elite into a narrative of the rise of "a strong secular elite and true kingship" from $c a .2600$ BC (Van De Mieroop 2002, 135).

In this article we consider new evidence for one attribute of political authority that has received little systematic attention since Margueron's (1982) and Heinrich's (1984) classic studies of 30 years ago: the Sumerian palace. Previously unpublished evidence from surface investigations at Abu Salabikh, South Mound, is here presented within the ongoing debate over the nature of kingship in the third millennium BC.

\section{Kingly and Queenly Origins}

The question of kings and kingship in early Sumer has been an integral component of the debate concerning early political authority (Heimpel 1992). Depictions on cylinder seals, statuary and in relief from the Late Uruk and Jemdet Nasr periods (3400-2900 BC) of a bearded, skirted figure engaging in activities such as hunting, building, and presiding over torture of captives have traditionally been characterised as representing a "priest-king" (Amiet 1986; Schmandt-Besserat 1993, 208-209; Nissen 2001, 157). More recent studies have proposed that the bearded, skirted figure of Late Uruk depictions may be understood as directly betokening true kingship, since the figure is depicted performing activities that later iconographic and textual sources associate with kings (Steinkeller 1999; Gibson 2010, 87). Marchesi and Marchetti's (2011; 186-196) detailed, contextual study of all known "priest-king" depictions, however, makes an intriguing case that the skirted figure consistently represents a male form of the goddess Inana, and has no direct connection to the origins of kingly authority in the third millennium BC.

In the centuries between 2900 and 2600 BC iconographic representations of kingship disappear almost totally from the archaeological record of Sumer, concurrent with a dramatic decrease in the evidence for imported exotic materials and for textual activity. These attributes in periods traditionally assigned as Early Dynastic I-II (leaving aside for now the issue of whether 
Early Dynastic II represents a genuine span of time) underpin Van De Mieroop's view of Sumer in the early third millennium BC as inward-looking and lacking external engagement, with little evidence of significant social stratification (Van De Mieroop 2002, 131-132), although Marchesi and Marchetti (2011, 98-100) contest that there is limited evidence for Sumerian kingship prior to 2600 BC.

With the onset of renewed external engagement from $2600 \mathrm{BC}$, we see once more the appurtenances of political authority manifest in the archaeological and textual records, including a surge in the appearance of statues with royal inscriptions (Marchesi and Marchetti 2011; Liverani 2014, 110). Suggestive of the apparent novelty of the institution of kingship from 2600 BC is the multiplicity of Sumerian terms employed to define it, including en, énsi, lugal and nun (Marchesi and Marchetti 2011, 103). Late Early Dynastic III texts from Ur, relating to offerings of animals "to the palace", make frequent mention of a lugal, often associated with more secular aspects of kingship, while also acting as an agent of the cult of Nanna and overseeing the distribution of fattened animals to his own palace, amongst other destinations at Ur and beyond (Visicato and Westenholz 2005).

Alongside kings and kingship we may consider the significance of queens and queenship. It is clear that Sumerian queens held positions of significant power and control, including over the administration of temple holdings, animals, lands and goods (Maekawa 1973-74). In a detailed study of several of the Early Dynastic IIIa tombs in the Royal Cemetery at Ur, McCaffery (2008) questions many of the unspoken gender biases in approaches to the Sumerian past. She points to evidence for "female kings" in the Sumerian King List and concludes that the Royal Cemetery contains the graves of both male and female rulers of Ur. By the Early Dynastic IIIb period a shift can be detected in the nature and representation of Sumerian kingship, with an increased emphasis on the social role of the king and political legitimisation, manifest in increased numbers of inscribed royal statues and their retention in temple repositories even after the death of individual kings (Marchesi and Marchetti 2011, 149-150). At the same time, kings, queens and their courts are increasingly depicted in glyptic and inlay art as participating in appropriately regal activities such as leading armies into battle (Miglus 2008) and banqueting (Marchesi and Marchetti 2011, 205). By 2400 BC the concept of the Mesopotamian king as divinely-sanctioned ruler, military leader and shepherd of his people had assumed the fulsome form that was to persist as a template of political supremacy through the centuries of the Bronze and Iron Ages to come.

\section{Sumerian Royal Residences}

Kings and queens must have their palaces, or they are not worthy of the title. Where are the palaces of the early Sumerian rulers? On this subject the existing evidence is not hugely informative. Arguments that the large building at Jemdet Nasr, dated by its associated pottery and proto-cuneiform texts to $c a .2900 \mathrm{BC}$, may have been a palace are not wholly convincing, even if the building can at least be interpreted as having a role at "the nexus of a complex web of social, economic, and religious interactions of a markedly centralised and regularised nature" (Matthews 2002, 35). By the Early Dynastic IIIa period the evidence is richer and we have the ground plans of several expansive, multi-room buildings which are too large and elaborate to 


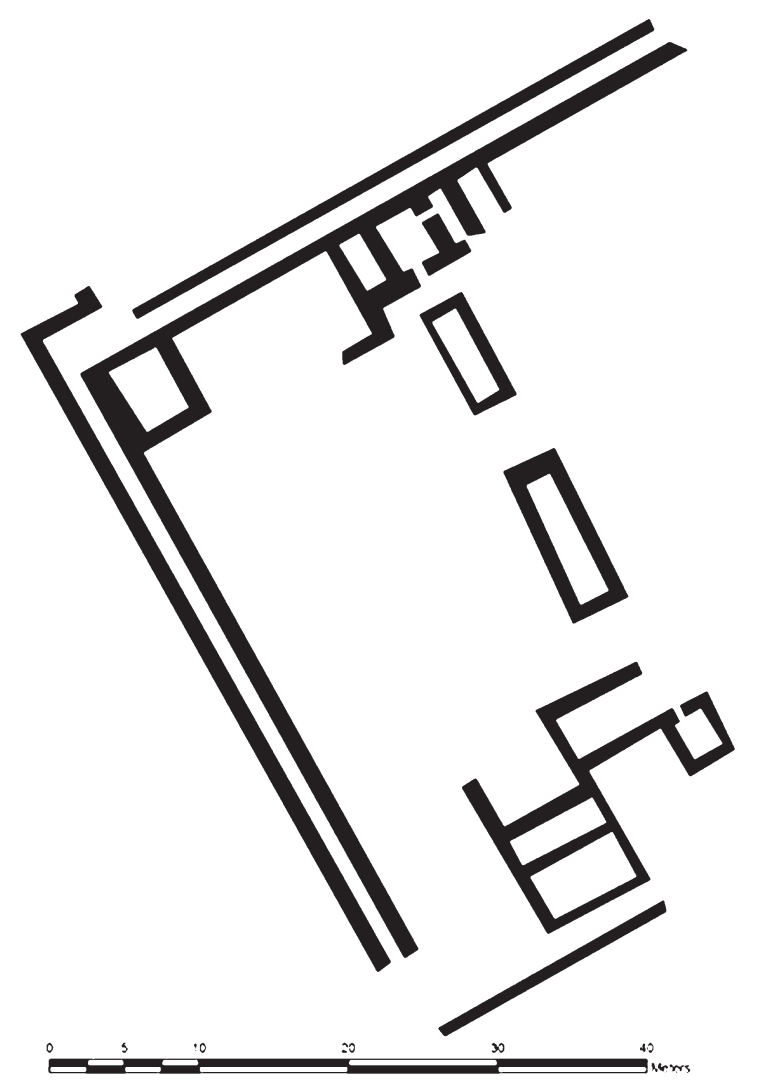

Fig. 1. Plan of the South Mound palace, Abu Salabikh. be domestic residences and whose layout differs significantly from those of temples, and may in short be interpreted as palaces. Such buildings have been excavated at Eridu (Safar et al. 1981) and arguably at Tell al-Wilayah in the south (Madhloom 1960, plan 2b), at Kish to the north of Sumer (Moorey 1964) and further north still at Mari (Margueron 1982), Ebla (Matthiae 2013) and Chuera (Akkermans and Schwartz 2003, 257-258). We may also add to these large buildings the unfinished Stampflehmgebäude at Uruk-Warka, probably constructed by the king Lugalzagesi at the very end of the Early Dynastic III period (Boehmer 1997, 295-296).

The ground plans of these buildings are characterised by large square courtyards surrounded by suites of rooms, thick external walls with or without buttressed facades, and long narrow corridors running between the external walls and the outer walls of rooms around the courtyards. Finds from within these buildings, where reported, indicate significant levels and variety of storage and craft production in specific areas of the palaces, including working of ivory, wood, and precious and semi-precious stones (Zaina 2015).

In addition to the double palace structure known as Palace A at Kish (Moorey 1964), recent study of satellite images has revealed the existence of at least three further palaces at Kish, each with the characteristic Early Dynastic III plan of double exterior walls and large courtyards with possible throne-rooms (Stone 2013, 164-165). As Stone has pointed out, the palaces at Eridu and Kish are located a significant distance from the main temples of their respective cities, arguably separated by major watercourses. These spatial attributes are seen as embodying "the practical and symbolic separation between the religious and secular which is the hallmark of Mesopotamian rule from this time forth" (Stone 2013, 164). The palace at Tell al-Wilayah is located in Area III at the extreme northwest corner of the large mound (Madhloom 1960, plan $1)$, also therefore distant from the city centre.

\section{A Previously Unpublished Palace from Abu Salabikh, South Mound}

During the 1988 and 1989 field seasons at Abu Salabikh, surface investigations took place for the first time on the South Mound, a low-lying spread of cultural remains covering some eight hectares in extent, situated to the south of the Main Mound which had been the main fo- 


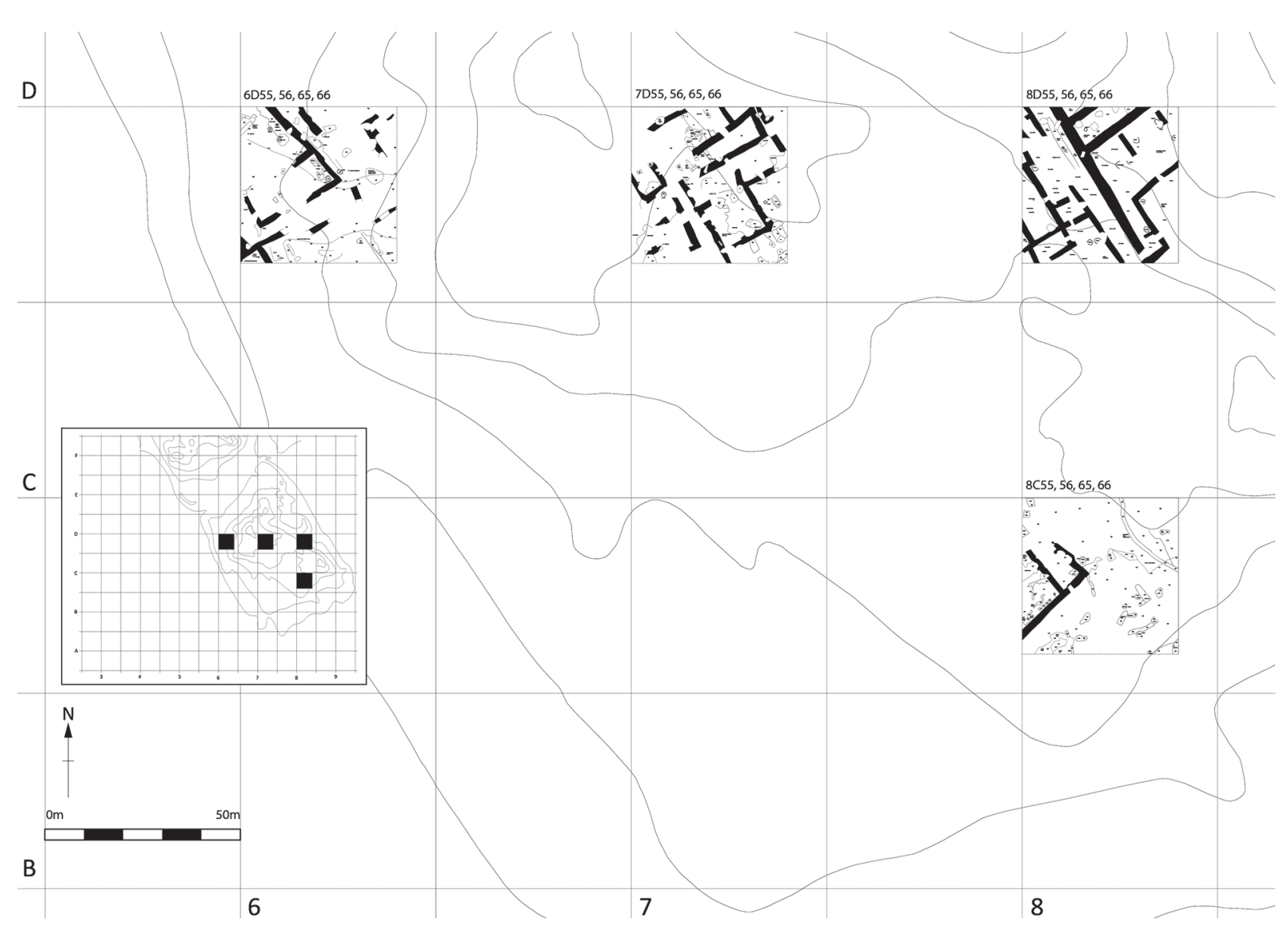

Fig. 2. Plan of architecture from surface cleaning of the South Mound, Abu Salabikh.

cus of excavation by both the 1960s Chicago team and the 1970s-1980s work directed by Nicholas Postgate (Postgate 1990, 104-106). At the conclusion of the 1989 season, one late afternoon we walked over the South Mound after a rain storm. Differential drying of deposits rendered visible the plan of a large building, situated between previously scraped and planned architecture in squares 7D and 8C. We were able to make a measured sketch of the visible walls and that plan is here published for the first time (Fig. 1). The building covers an area of at least 50 by $50 \mathrm{~m}$, and has features characteristic of an Early Dynastic III palace, in particular the parallel double exterior walls, clearly visible on the northwest and southwest side of the building. A wall return at the northwest corner may suggest that this structure is one of a complex of palaces or structures, as attested in the new evidence from Kish published by Stone and discussed above (Stone 2013). Rooms within the enclosing wall were only partly visible, as depicted on the plan, and occasional spreads of baked brick (flooring?) were also visible within the central area of the building.

Surface scraping and planning on the South Mound at Abu Salabikh in 1988-1989 had already revealed spreads of Early Dynastic III architecture in northwest-southeast alignments, as here published also for the first time. Four sample squares, each 20 by $20 \mathrm{~m}$, were scraped 
and planned, three of them across the centre of the South Mound and one to the south (Fig. 2). In all of them, walls of unbaked mud-bricks, with rare use of baked bricks, were exposed. The wall alignments are northwest-southeast and northeast-southwest as with all structures across the entire city (Matthews and Postgate 1987, fig. 5). In addition to the walls, a great many fire installations were cleaned and recorded across the scraped areas. Finds from within and around the rooms include typical Early Dynastic III pottery, including complete examples of uprighthandled jars, a single cylinder seal, stone bowl sherds, and large quantities of flint-working debitage in particular from squares 8C55 and 8C65.

The precise location of the new palace depicted in Fig. 1 remains to be established. At the time, we noted that it was located between squares $7 \mathrm{D}$ and $8 \mathrm{C}$, roughly in the middle of the plan produced in Fig. 1. It might therefore be the case that at least some of the already planned walls also belong to the palace or palace complex. The walls in square $8 \mathrm{C}$, in particular, have a regularity and substantial thickness that suggest they belong to a supra-domestic or large household structure. As mentioned above, it may be the case that more than one palace or structure is represented by these surface traces.

It is tempting to associate the physical remains of the South Mound palace with the textual evidence from Abu Salabikh itself which appears to refer to the "king's field(s)" and a "king of Ereš" (where Ereš might be identified with Abu Salabikh) (Krebernik and Postgate 2009, 7). As with the palaces at Eridu, Kish and Tell al-Wilayah discussed above, the Abu Salabikh palace is located distant from what appears to be the main temple area in Area E of the Main Mound and is probably separated from it by a watercourse, supporting Stone's argument (2013) of a physical separation of secular and religious power at the nascence of kingship in Sumer.

As we walked over the mound that late spring afternoon in 1989, we fully expected to return to Abu Salabikh for further fieldwork which would include investigation of the South Mound palace. We did revisit the site during spring 1990, a year after sketching the palace, but could not detect any trace of the walls on that occasion. In more recent years, analysis of satellite and helicopter imagery of the site has failed to detect convincing evidence for the South Mound palace. Clearly, the conditions of differential drying after rain are essential before the palace shows itself as surface markings once more. Until that time, and until it becomes possible once more to work at the site, we hope that the Abu Salabikh South Mound palace will continue to keep firm hold of its long-guarded secrets.

\section{Acknowledgements}

We are grateful to Elizabeth Stone for helpful comments and for access to recently taken remote imagery of Abu Salabikh, and to Helen McGauran for assistance with the plans produced here.

\section{References}

Akkermans, P. M. M. G. and Schwartz, G. M.

2003 The Archaeology of Syria. From Complex Hunter-Gatherers to Early Urban Societies (ca. 16,000-300 $B C$ ). Cambridge: Cambridge University Press. 
Algaze, G.

1993 The Uruk World System. The Dynamics of Expansion of Early Mesopotamian Civilization. Chicago: University of Chicago Press.

Amiet, P.

1986 Le problème de l'iconographie divine en Mésopotamie dans la glyptique antérieure à l'époque d'Agadé. Contributi e Materiali di Archeologia Orientale 1: 1-65.

Boehmer, R. M.

1997 Uruk-Warka. Pp. 294:98 in The Oxford Encyclopedia of Archaeology in the Near East. (Volume 5), ed. E. M. Meyers. Oxford: Oxford University Press, 294-298.

Deimel, A.

1920 Die Reformtexte Urukaginas. (Orientalia 2). Rome: Orientalia Special Publication.

1931 Sumerische Tempelwirtschaft zur Zeit Urukaginas und seiner Voregänger. (Analecta Orientalia 2). Rome: Pontifical Biblical Institute.

Diakonoff, I. M.

1974 Structure of society and state in Early Dynastic Sumer. Monographs of the Ancient Near East I/3: $1-16$.

Englund, R. K.

1998 Texts from the Late Uruk period. Pp. 13-233 in Mesopotamien. Späturuk-Zeit und Frühdynastische Zeit, eds. J. Bauer, R. K. Englund and M. Krebernik. Freiburg: Schweiz.

Falkenstein, A.

1954 La Cité Temple sumérienne. Journal of World History 1: 784-814.

1974 The Sumerian Temple City. Malibu: Undena.

Foster, B.

1981 A new look at the Sumerian temple state. Journal of the Economic and Social History of the Orient 24: 225-241.

Gelb, I. J.

1969 On the alleged temple and state economies in ancient Mesopotamia. Studi in onore di Edoardo Volterra 6: 137-154.

Gibson, McG.

2010 The dead hand of Deimel. Pp. 85-92 in Beyond the Ubaid. Transformation and Integration in the Late Prehistoric Societies of the Middle East, eds. R. A. Carter and G. Philip. (Studies in Ancient Oriental Civilization 63). Chicago: The Oriental Institute of the University of Chicago.

Heimpel, W.

1992 Herrentum und Königtum im vor- und frühgeschichtlichen Alten Orient. Zeitschrift für Assyriologie 82: 4-21.

Heinrich, E.

1984 Die Paläste im alten Mesopotamien. Berlin: de Gruyter.

Jacobsen, $\mathrm{T}$.

1957 Early political developments in Mesopotamia. Zeitschrift für Assyriologie 52: 91-140.

Krebernik, M.

1998 Die Texte aus Fāra und Tell Abū Salābīh. Pp. 235-427 in Mesopotamien. Späturuk-Zeit und Frühdynastische Zeit, eds. J. Bauer, R. K. Englund and M. Krebernik. Freiburg: Schweiz.

Krebernik, M. andPostgate, J.N.

2009 The tablets from Abu Salabikh and their provenance. Iraq 71: 1-32.

Liverani, M.

2014 The Ancient Near East. History, Society and Economy. Abingdon: Routledge.

Madhloom, T. A. W.

1960 The excavations at Tell al-Wilaya (in Arabic). Sumer 16: 62-92.

Maekawa, K.

1973-74 The development of the É-MÍ in Lagash during Early Dynastic III. Mesopotamia 8-9: 77-144. 
Marchesi, G. and Marchetti, N.

2011 Royal Statuary of Early Dynastic Mesoptamia. Winona Lake: Eisenbrauns.

Margueron, J.-C.

1982 Recherches sur les palais mésopotamiens de l'Age de Bronze. Paris: Geuthner.

Martin, H. P.

1988 Fara. A Reconstruction of the Ancient Mesopotamian City of Shuruppak. Birmingham: Chris Martin.

Matthews, R.

1991 Fragments of officialdom from Fara. Iraq 53: 1-15.

2002 Secrets of the Dark Mound. Jemdet Nasr 1926-1928. Warminster: British School of Archaeology in Iraq.

2003 The Archaeology of Mesopotamia. Theories and Approaches. London: Routledge.

Matthews, R. J. and Postgate, J.N.

1987 Excavations at Abu Salabikh, 1985-86. Iraq 49: 91-119.

Matthiae, P.

2013 The royal palace. Functions of the quarters and government of the chora. Pp. 49-65 in Ebla and its Landscape. Early State Formation in the Ancient Near East, eds. P. Matthiae and N. Marchetti. Walnut Creek: Left Coast Press, 49-65.

McCaffery, K.

2008 The female kings of Ur. Pp. 173-215 in Gender Through Time in the Ancient Near East, ed. D. Bolger. Plymouth: AltaMira.

Miglus, P.

2008 Kings go into battle. Representation of the Mesopotamian ruler as a warrior. Pp. 231-246 in Les armées du Proche-Orient ancient (III ${ }^{e}-I^{e r}$ mill. av. J.-C.), eds. P. Abraham and L. Battini. Oxford: British Archaeological Reports (International Series 1855).

Moorey, P. R. S.

1964 The plano-convex building at Kish and early Mesopotamian palaces. Iraq 26: 83-98.

1999 Ancient Mesopotamian Materials and Industries: The Archaeological Evidence. Winona Lake, IN: Eisenbrauns.

Nissen, H. J.

2001 Cultural and political networks in the ancient Near East during the fourth and third millennia B.C.. Pp. 149-179 in Uruk Mesopotamia and its Neighbors. Cross-Cultural Interactions in the Era of State Formation, ed. M. S. Rothman. Sante Fe: School of American Research Press, 149-179.

Potts, D. T.

1997 Mesopotamian Civilization. The Material Foundations. London: Athlone Press.

Postgate, J. N.

1990 Excavations at Abu Salabikh, 1988-89. Iraq 52: 95-106.

Safar, F., Mustafa M. A. and Lloyd S.

1981 Eridu. Baghdad: State Organization of Antiquities and Heritage.

Schmandt-Besserat, D.

1993 Images of Enship. Pp. 201-219 in Between the Rivers and Over the Mountains: Archaeologica Anatolica et Mesopotamica Alba Palmieri Dedicata, eds. M. Frangipane et al. Rome: Università di Roma "La Sapienza", 201-219.

Schneider, A.

1920 Die Anfänge der Kulturwirtschaft: Die sumerische Tempelstadt. Essen: Baedeker.

Smith, A. T.

2003 The Political Landscape. Constellations of Authority in Early Complex Polities. Berkeley: University of California Press.

Starzmann, M. T.

2007 Archäologie des Raumes. Soziale Praxis und kulturelle Bedeutung am Beispiel der Wohnarchitektur von Fara. Berlin: Lit Verlag. 
Steinkeller, P.

1999 On rulers, priests and sacred marriage: tracing the evolution of early Sumerian kingship. Pp. 103-137 in Priests and Officials in the Ancient Near East, ed. K. Watanabe. Heidelberg: Carl Winter.

Stone, E. C.

2013 The organisation of a Sumerian town: the physical remains of ancient social systems. Pp. 156178 in The Sumerian World, ed. H. Crawford. Abingdon: Routledge.

Suter, C. E.

2013 Kings and queens: representation and reality. Pp. 201-226 in The Sumerian World, ed. H. Crawford. Abingdon: Routledge.

Van De Mieroop, M.

2002 In search of prestige: foreign contacts and the rise of an elite in Early Dynastic Babylonia. Pp. 125-137 in Leaving No Stones Unturned. Essays on the Ancient Near East and Egypt in Honor of Donald P. Hansen, ed. E. Ehrenberg. Winona Lake: Eisenbrauns.

Visicato, G. and Westenholz, A.

2005 An Early Dynastic archive from Ur involving the lugal. Kaskal. Rivista di storia, ambienti e culture del Vicino Oriente Antico 2: 55-78.

Zaina, F.

2015 Craft, administration and power in Early Dynastic Mesopotamian public buildings. Recovering the Plano-Convex Building at Kish, Iraq. Paléorient 41: 179-199.

Zettler, R. L. and Horne, L. (eds)

1998 Treasures from the Royal Tombs of Ur. Philadelphia: University of Pennsylvania Museum of Archaeology and Anthropology. 
